\title{
PERLINDUNGAN HUKUM BAGI KREDITUR PEMEGANG HAK TANGGUNGAN TERHADAP SENGKETA AGUNAN YANG MENGAKIBATKAN BATALNYA PERJANJIAN KREDIT
}

\author{
Fransisca Kusuma Aryani \\ (Mahasiswa Program S1 Fakultas Hukum Universitas Tarumanagara) \\ (E-mail: fransiscakusuma_a@yahoo.co.id)
}

\section{Gunawan Djajaputra}

(Corresponding Author)

(Dosen Hukum Agraria Fakultas Hukum Universitas Tarumanagara, Meraih Sarjana Hukum dari

Fakultas Hukum Universitas Indonesia, Magister Hukum dari Fakultas Hukum Universitas Indonesia, Doktor Hukum dari Fakultas Hukum Universitas Indonesia)

(E-mail: gunawand@fh.untar.ac.id)

\begin{abstract}
The process of granting credit with the guarantee of Mortgage Rights experienced many obstacles, one of which is the cancellation of credit agreement due to a lawsuit from a third party. Examples of problems that will researchers take is a case between PT PNM as creditor and Erlinawati as a debtor. Erlinawati applied for credit to PT PNM and pledged SHM No. 1716 without her husband's agreement, Bagus Satriya. As time went by, Erlinawati could not fulfill its obligations as stipulated in the credit agreement, and then PT PNM sent a warning letter to Erlinawati. Good people who know the land and buildings of his property are used as a direct guarantee to file a lawsuit to the Blora District Court. The Blora District Court ruled that credit agreements and Deed of Mortgage Rights (APHT) are invalid and null and void. So far the legal protection for debtors who have sued from the other party on the guarantee given by the creditor has not been regulated specially in the legislation. The law only regulates bad debts and debt repayment through the execution process stipulated in the Law on Banking and Insurance Rights Act. Legal protection that creditor can use when obtaining a lawsuit from a third party is by using the general guarantees provided for in Articles 1131 and 1132 of the Civil Code.
\end{abstract}

Keywords: Protection of the Law, Cancellation of Credit Agreement, Dependent Liability 


\section{Pendahuluan}

\section{A. Latar belakang}

Bank merupakan lembaga keuangan negara yang memegang peranan penting dalam pergerakan perekonomian negara. Fungsi bank menurut ketentuan Pasal 2 Undang Undang Nomor 7 Tahun 1992 tentang Perbankan jo Undang Undang 10 Tahun 1998 tentang Perbankan yang selanjutnya disingkat UU Perbankan adalah menghimpun dana dan menyalurkan dana kepada masyarakat dengan tetap bertujuan menunjang pembangunan nasional. Perbankan di Indonesia mempunyai tujuan yang strategis dan tidak semata-mata berorientasi ekonomis, tetapi juga berorientasi kepada hal-hal yang non ekonomis seperti masalah menyangkut stabilitas politik dan stabilitas sosial.Berkaitan dengan upaya peningkatan perekonomian masyarakat, maka perlu dilaksanakan programprogram yang dapat melaksanakan taraf hidup masyarakat. Salah satu program tersebut adalah pemberian kredit kepada masyarakat sehingga dapat memperkuat pemodalan yang dapat meningkatkan taraf hidup masyarakat pada umumnya ${ }^{1)}$

Pemberian kredit merupakan suatu perjanjian utang piutang antara bank selaku kreditur dengan masyarakat selaku debitur yang ditekankan kepada kesepakatan para pihak yaitu berdasar pada kebebasan dalam membuat perikatan yang diatur dalam Pasal 1329 Kitab Undang Undang Hukum Perdata yang menyatakan bahwa: "Tiap orang berwenang untuk membuat perikatan, kecuali jika ia dinyatakan tidak cakap untuk hal itu." Berdasarkan persetujuan atau kesepakatan utang-piutang antara bank dengan pihak lain yang mewajibkan pihak berhutang untuk melunasi utangnya setelah jangka waktu tertentu dengan pemberian bunga. Pelaksanaan pemberian kredit bank haruslah hati-hati, sebagaimana dituangkan dalam Pasal Perbankan yang menyebutkan bahwa perbankan Indonesia dalam melakukan usahanya wajib berasaskan demokrasi ekonomi dengan menggunakan prisip kehati-hatian.Bank dalam pemberian kredit wajib mempunyai keyakinan berdasarkan analisis yang mendalam atas itikad dan kemampuan serta kesanggupan nasabah debitur untuk melunasi hutangnya atau mengembalikan pembiayaan sesuai yang sudah diperjanjikan. Guna memperoleh

\footnotetext{
${ }^{1)}$ Hermansyah, Hukum Perbankan Nasional Indonesia, (Jakarta: Kencana, 2005), hal. 20.
} 
keyakinan atas kemampuan dan kesanggupan Debitur tersebut, maka sebelum memberikan kredit bank harus melakukan penilaian yang seksama. Penilaian kredit merupakan kegiatan untuk menilai keadaan calon debitur dan penilaian atas analisis kredit ini akan sangat mempengaruhi kualitas portofolio Kredit Bank. ${ }^{2)}$

Jaminan yang sering digunakan bank dalam pelaksanaan kredit adalah jaminan yang berupa benda tidak bergerak atau tanah, karena tanah mempunyai nilai ekonomi yang tinggi dan tidak akan mengalami penurunan nilainya. ${ }^{3)}$ Penjelasan Pasal 8 ayat (1) UU Perbankan menerangkan bahwa agunan merupakan salah satu unsur pemberian kredit. Agunan sendiri dapat diartikan dalam penjelasan Pasal 1 ayat (23) UU Perbankan bahwa "agunan merupakan jaminan tambahan yang diserahkan Nasabah Debitur kepada bank dalam rangka pemberian fasilitas kredit atau pembiayaan berdasarkan Prinsip Syariah". Agunan merupakan jaminan yang diberikan setelah dibuat perjanjian kredit di bank.Perjanjian penjaminan merupakan perjanjian yang bersifat accesoir atau perjanjian tambahan. Peraturan tentang jaminan ini terdapat di buku kedua Kitab Undang-Undang Hukum Perdata yaitu tentang prinsip-prinsip hukum jaminan dan lembaga-lembaga jaminan. ${ }^{4}$

Fungsi jaminan sebagai salah satu aspek penilaian dalam analisis kredit adalah sebagai alat pengamanan terhadap kemungkinan adanya Debitur yang tidak membayar kembali kredit yang diterimanya. ${ }^{5)}$ Jaminan terdiri dari 2 yaitu jaminan yang bersifat umum dan jaminan yang bersifat khusus. Jaminan yang bersifat umum yaitu jaminan yang diberikan oleh debitur kepada kreditur, hak-hak tagihan mana tidak mempunyai hak saling mendahului (konkuren) antara kreditur yang satu dengan kreditur lainnya. Jaminan yang bersifat khusus adalah jaminan yang diberikan oleh debitur kepada kreditur, hak-hak tagihan mana mempunyai

2)Dahlan Siamat, Manajemen Lembaga Keuangan, (Jakarta:Intermedia, 1995), hal.99.

3)Habib Adjie, Hak Tanggungan sebagai Lembaga Jaminan atas Tanah, (Bandung: Mandar Maju, 2000), hal. 2.

4)Indonesia, Undang-undang Nomor 10 Tahun 1998 tentang Perubahan Undang-undang Nomor 7 Tahun 1992 tentang Perbankan (Tambahan Lembaran Negara Republik Indonesia Nomor 3472), Pasal 1.

5)Dahlan Siamat, Op.Cit., hal.100. 
hak mendahului sehingga ia berkedudukan sebagai kreditur previlage (hak preverent). ${ }^{6)}$

Benda yang dapat dijadikan pelunasan jaminan umum apabila telah memenuhi persyaratan antara lain :

1.Benda tersebut bersifat ekonomis (dapat dinilai dengan uang).

2.Benda tersebut dapat dipindah tangankan haknya kepada pihak lain.

Pelunasan hutang dengan jaminan khusus merupakan hak khusus pada jaminan tertentu bagi pemegang gadai, hipotik, hak tanggungan, dan fidusia.Salah satu jaminan yang sering digunakan debitur adalah menjaminkan suatu tanah miliknya yang kemudian dibebani dengan Hak Tanggungan.Undang-Undang Nomor 4 Tahun 1996 tentang Hak Tanggungan Atas Tanah Beserta Benda-Benda Yang Berkaitan Dengan Tanah, yang selanjutnya disingkat UU Hak Tanggungan, menyebutkan bahwa Hak Tanggungan adalah hak jaminan yang dibebankan pada hak atas tanah berikut atau tidak berikut benda benda lain yang merupakan satu kesatuan dengan tanah itu, untuk pelunasan utang tertentu terhadap kreditur kreditur lain.

Pelaksanaan praktek kredit banyak dijumpai bahwa tidak semua debitur dapat memenuhi prestasinya yaitu membayar hutang. Berdasarkan ketentuan Pasal 6 UU Hak Tanggungan menyatakan bahwa apabila debitur cidera janji, pemegang Hak Tanggungan pertama mempunyai hak untuk menjual objek Hak Tanggungan atas kekuasaan sendiri melalui pelelangan umum serta mengambil pelunasan piutangnya dari hasil penjualan asset tersebut. Proses eksekusi yang dilakukan oleh pihak Kreditur sering dijumpai banyak kendala salah satunya adalah terjadinya gugatan dari pihak lain yang berhak atas objek jaminan yang dijadikan Hak Tanggungan.

Contoh kasus yang akan peneliti ambil adalah kasus Putusan Mahkamah Agung Republik Indonesia yang terdaftar dengan Nomor 1217 K/Pdt/2016. Kasus bermula dari adanya perjanjian utang piutang yang dilakukan oleh Erlinawati dan PT Permodalan Nasional Madani. Perjanjian ini merupakan kesepakatan antara PT Permodalan Nasional Madani dimana PT Permodalan Nasional Madani akan

\footnotetext{
6)Hasanuddin Rahman,Aspek-Aspek Hukum Pemberian Kredit Perbankan di Indonesia, (Bandung : PT Citra Aditya Bakti, 1995), hal. 174.
} 
memberikan fasilitas kredit kepada Erlinawati sebesar Rp 68.192.050,- (enam puluh delapan juta seratus sembilan puluh dua ribu lima puluh rupiah)

Bagus Sariya Wicaksono Bin Bambang Siswoyo dan Erlinawati adalah sepasang suami istri yang sah. Selama dalam perkawinan mereka, mereka membeli:

1. Pada tanggal 27 Januari 2011 telah membeli sebidang tanah berdiri di atasnya sebuah bangunan rumah permanen Sertifikat Hak Milik Nomor 1910 atas nama Bagus Satria Wicaksono seluas $375 \mathrm{M}^{2}$ terletak di Jalan Lorong Distrik C/18 Kelurahan Cepu RT 005 RW 009, Kecamatan Cepu, Kabupaten Blora, Jawa Tengah dengan batas-batas yaitu: sebelah Utara: tanah Sutrimo, sebelah Timur: tanah Suparmi, Heri, sebelah Selatan: Lorong Distrik, sebelah Barat: tanah B. Markum;

2. Pada tanggal 24 Mei 2011 telah membeli sebidang tanah dan mendirikan bangunan rumah permanen (rumah kos) dengan Sertifikat Hak Milik Nomor 1716 atas nama Erlinawati seluas $265 \mathrm{M}^{2}$ terletak di Jalan Raya Cepu - Randublatung, Kelurahan Tambakromo, Kecamatan Cepu, Kabupaten Blora, Jawa Tengah dengan batas-batas yaitu: sebelah Utara: Tanah Hak Nomor 04612, sebelah Timur: tanah Suwardi, sebelah Selatan: Jalan Raya, sebelah Barat: Tanah Hak Nomor 04510;

Tanah dan rumah tersebut di atas disebut sebagai harta bersama (gonogini) dari Bagus dengan Erlinawati. Tahun 2013 perkawinan mereka goyah dan mereka tidak tinggal satu rumah lagi. Bagus tidak pernah pulang dari pekerjaan di Kalimantan sedangkan tetap di rumah di Jalan Lorong Distrik C/18 Kelurahan Cepu RT 005 RW 009 Kecamatan Cepu Kabupaten Blora Jawa Tengah dan sejak saat itu juga Erlinawati telah menjalin hubungan cinta dengan laki laki lain bernama Mahendra Baihaki. Tanggal 1 Agustus 2013 Erlinawati telah mengajukan kredit kepada PT Permodalan Nasional Madani unit Cepu dengan menggunakan jaminan/agunan sebidang tanah dan bangunan rumah permanen (rumah kos) dengan Sertifikat Hak Milik Nomor 1716 atas nama Erlinawati seluas $265 \mathrm{M}^{2}$ terletak di Jalan Raya Cepu - Randublatung, Kelurahan Tambakromo, Kecamatan Cepu, Kabupaten Blora, Jawa Tengah tanpa tanpa ada persetujuan ijin dari Bagus selaku suami sah dari Erlinawati.

Pengajuan kredit dari Erlinawati dan orang yang mengatas namakan dirinya bernama Bagus Satriya Wicaksono telah disetujui dan dituangkan dalam Perjanjian Kredit Nomor 45 tertanggal 16 Agustus 2013. Mereka juga telah 
membuat Akta Pengikatan Hak Tanggungan (APHT) yang dibuat oleh Notaris/ PPAT Wahyu Widyastuti, SH atas sebidang tanah dengan Sertifikat Hak milik (SHM) 1716 atas nama Erlinawati.

Bagus yang mengetahui harta bersama miliknya dipakai sebagai jaminan/ agunan kredit langsung mengajukan komplain kepada PT Permodalan Nasional Madani untuk membatalkan jaminan atas SHM No 1716 atas nama Erlinawati, namun ditolak oleh PT Permodalan Nasional Madani. Bagus merasa tidak pernah mengajukan permohonan kredit dan menandatangani perjanjian kredit serta tidak pernah menandatangani Akta Pengikatan Hak Tanggungan (APHT), maka secara hukum atas jaminan atas tanah dan bangunan rumah permanen dengan SHM No. 176 atas nama Erlinawati yang telah diterima oleh PT Permodalan Nasional Madani sepatutnya dinyatakan batal atau dapat dibatalkan sehingga dokumen kredit tersebut tidak mempunyai kekuatan hukum.

Bagus telah berusaha untuk menempuh jalan damai dalam menyelesaikan perkara tersebut dengan menghubungi Erlinawati istri sah nya namun tidak berhasil. Bagus juga menemui PT Permodalan Nasional Madani dan Notaris/ PPAT Wahyu Widyastuti, SH agar mengembalikan SHM No. 176 atas nama Erlinawati namun tidak berhasil, sehingga Bagus harus mengajukan gugatan tersebut ke Pengadilan Negeri Blora dan Pengadilan Negeri Blora telah menyatakan bahwa:

1. Menyatakan sah menurut hukum atas tanah dan rumah sebagai harta bersama (gono-gini) antara Bagus dan Erlinawati

2. Menyatakan Erlinawati menjaminkan/mengangunkan atas tanah dan mendirikan bangunan rumah permanen (rumah kos) dengan Sertifikat Hak Milik atas nama Erlinawati seluas $265 \mathrm{M}^{2}$ terletak di Jalan Raya Cepu Randublatung, Kelurahan Tambakromo, Kecamatan Cepu, Kabupaten Blora, Jawa Tengah, dengan batas-batas yaitu: sebelah Utara: Tanah Hak Nomor 04612, sebelah Timur: tanah Suwardi, sebelah Selatan: Jalan Raya, sebelah Barat: Tanah Hak Nomor 04510, kepada PT Permodalan Nasional Madani sebagai jaminan hutang (kredit) tanpa persetujuan dari Bagus adalah batal menurut hukum

3. Menyatakan dokumen kredit berupa Permohonan Pengajuan Kredit tertanggal 1 Agustus 2013, Perjanjian Kredit antara Erlinawati dan orang yang mengatas namakan dirinya bernama Bagus Satriya Wicaksono dengan yaitu Perjanjian Kredit Nomor 45 tertanggal 16 Agustus 2013, dan juga Akta Pengikatan Hak Tanggungan Tanah (APHT) Nomor 542/CP/2013 
tertanggal 21 Agustus 2013 dengan nilai hak tanggungan sebesar Rp80.000.000,00 (delapan puluh juta rupiah) yang dibuat oleh Notaris/PPAT Wahyu Widyastuti, S.H., tidak sah dan tidak mempunyai kekuatan hukum;

4. Menghukum kepada Erlinawati dan PT Permodalan Nasional Madani atau siapa saja yang mendapatkan hak atau kuasa dari padanya untuk menyerahkan/ mengembalikan tanah dan bangunan rumah permanen (rumah kos) dengan Sertifikat Hak Milik Nomor 1716 atas nama Erlinawati seluas $265 \mathrm{M}^{2}$ terletak di Jalan Raya Cepu - Randublatung, Kelurahan Tambakromo, Kecamatan Cepu, Kabupaten Blora, Jawa Tengah, dengan batas-batas yaitu: sebelah Utara: Tanah Hak Nomor 04612, sebelah Timur: tanah Suwardi, sebelah Selatan: Jalan Raya, sebelah Barat: Tanah Hak Nomor 04510, dalam keadaan kosong tanpa dibebani hak tanggungan hutang kepada Penggugat dan tanpa beban apapun, dan bilamana Erlinawati dan PT Permodalan Nasional Madani ingkar maka pelaksanaanya mohon bantuan alat Negara (Polisi);

Selanjutnya PT Permodalan Nasional Madani selaku kreditur mengajukan gugatan kepada Pengadilan Tinggi Semarang dimana hasil putusannya yang tercantum dalam putusan Pengadilan Tinggi Semarang Nomor: 332/PDT./2015/PT.MG. tanggal 25 Oktober 2015 dimana menerima permohonan banding dari PT Permodalan Nasional Madani selaku kreditur dan menguatkan putusan Pengadilan Negeri Blora tanggal 23 April 2015, Nomor : 26/Pdt.G/2014/PN.Bla.

Kreditur dalam hal ini kemudian mengajukan banding kepada Mahkamah Agung RI yang hasil putusannya tercantum dalam putusan Mahkamah Agung RI Nomor 1217K/Pdt/2016 tanggal 23 Agustus 2016. Hasil putusannya adalah menolak permohonan kasasi dari Pemohon Kasasi dari PT. Permodalan Nasional Madani (Persero) Unit Cepu tersebut dan menghukum Pemohon Kasasi/Tergugat II/Pembanding untuk membayar biaya perkara dalam tingkat kasasi ini sejumlah Rp500.000,00 (lima ratus ribu rupiah).

\section{B. Perumusan Masalah}

Berdasarkan latar belakang yang telah diuraikan sebelumnya, maka untuk lebih memfokuskan penelitian ini dirumuskan permasalahan sebagai berikut:

1. Bagaimana bentuk perlindungan hukum bagi kreditur pemegang Hak Tanggungan terhadap sengketa agunan yang mengakibatkan batalnya perjanjian kredit? 
2. Bagaimana upaya hukum yang dapat ditempuh kreditur untuk melindungi hak hak nya terhadap sengketa agunan yang mengakibatkan batalnya perjanjian kredit?

\section{Pembahasan}

\section{A. Perlindungan hukum bagi kreditur pemegang Hak Tanggungan terhadap sengketa agunan yang mengakibatkan batalnya perjanjian kredit}

Pelaksanaan kredit di Bank PT Permodalan Nasional Madani unit Cepu tidak semua berjalan lancar, terdapat pula kredit bermasalah.Kredit bermasalah yang dialami PT Permodalan Nasional Madani unit Cepu adalah adanya gugatan pihak lain yang berhak atas objek jaminan yang dibebani Hak Tanggungan. Pasal 20 UUHak Tanggungan yang mengatur tentang proses eksekusi mengatakan bahwa pemegang Hak Tanggungan yang akan menjual obyek Hak Tanggungan tidak perlu meminta persetujuan dari pemberi Hak Tanggungan dan eksekusinya harus dilakukan di pelelangan umum. Pasal 21 UUHak Tanggungan juga mengatur bahwa obyek Hak Tanggungan tidak akan disatukan dengan harta kepailitan untuk dibagi kepada kreditur kreditur lain dari pemberi Hak Tanggungan. Ketentuan ini memberi penegasan tentang kedudukan yang preferen dari pemegang Hak Tanggungan terhadap obyek Hak Tanggungan dan terhadap kreditur kreditur lain. Pihak Bank PT Permodalan Nasional Madani disini berkedudukan sebagai kreditur preferen sehingga seharusnya memiliki kedudukan yang diutamakan.

Munculnya gugatan dari pihak lain yang berhak atas objek jaminan yang dibebani hak tanggungan memberikan kesulitan untuk Bank sebagai kreditur. Posisi Bank selalu dianggap kuat tidak selamanya mendapatkan perlindungan hukum.Masih terdapat celah Bank dalam hal tidak mendapatkan perlindungan hukum sebagai pemilik hak preferen.Pasal 1 ayat (1) UU Hak Tanggungan memberikan kedudukan yang diutamakan atau didahulukan kepada pemegang Hak Tanggungan atau kreditur lainnya (droit de preference).Hak hak Kreditur yang didahulukan ini merupakan salah satu wujud perlindungan hukum yang diberikan bagi pihak kreditur apabila terjadi wanprestasi dari debitur, khususnya 
dalam pelunasan piutangnya. Beberapa kasus gugatan pihak lain yang berhak atas sengketa agunan membuktikan bahwa kepentingan kreditur belum sepenuhnya terlindungi. Pasal 11 UU Perbankan mengatur bahwa bank harus mengurangi resiko terhambatnya pelunasan piutang sesuai prinsip bank syariah karena hal tersebut mempengaruhi kesehatan bank dan keamanan dana masyarakat.

Upaya perlindungan preventif yang dapat dilakukan bank adalah dengan menerapkan prinsip kehati-hatian.UU Perbankan telah menganjurkan agar bank selalu berpegang pada prinsip kehati hatian dalam melaksanakan kegiatan usahanya termasuk dalam pemberian kredit.Pasal 2 UU Perbankan menyebutkan "Perbankan Indonesia dalam melakukan usahanya berasaskan demokrasi ekonomi dengan menggunakan prinsip kehati-hatian". Pasal 8 ayat (1) dan Pasal 8 ayat (2) juga berbunyi:

1. Dalam memberikan kredit atau pembiayaan berdasarkan Prinsip Syariah, Bank Umum wajib mempunyai keyakinan berdasarkan analisis yang mendalam atas itikad dan kemampuan serta kesanggupan nasabah debitur untuk melunasi utangnya atau mengembalikan pembiayaan dimaksud sesuai dengan diperjanjikan.

2. Bank Umum wajib memiliki dan menerapkan pedoman perkreditan dan pembiayaan berdasarkan Prinsip Syariah, sesuai dengan ketentuan yang ditetapkan oleh Bank Indonesia.

Pasal 2 dan 8 UU Perbankan merupakan dasar bagi Bank dalam memberikan kredit kepada calon debitur. Seorang debitur untuk memperoleh kredit harus melalui beberapa tahapan mulai dari pengajuan aplikasi kredit sampai dengan tahapan penerimaan kredit. Proses atau tahapan itu menjadi proses wajib yang harus dilakukan debitur yang membutuhkan kredit bank.

Proses pemberian kredit oleh Bank secara umum yaitu: ${ }^{7)}$

1. Permohonan kredit

Pemberian kredit oleh Bank harus didasarkan pada permohonan tertulis dari calon debitur atau berdasarkan penawaran dari bank yang disepakati calon debitur.

2. Pengumpulan informasi dan dokumen

\footnotetext{
7 Anonim, "Proses Pemberian Kredit", http://www.upacaya.com/proses-pemberian-kredit/, diakses tanggal 5 April 2018.
} 
Langkah awal dalam rangka penyusunan analisis kredit adalah mengumpulkan data dari calon debitur. Data yang diperlukan disesuaikan dengan jenis, nilai kredit, dan identitas calon debitur yang diberikan, antara lain:

a. Permohonan kredit;

b. Dokumen perizinan/surat keterangan usaha;

c. Dokumen identitas nasabah;

d. Laporan keuangan;

e. Laporan kredit nasabah (credit history) apabila debitur sebelumnya telah mendapat fasilitas pinjaman dari bank;

f. Copy dokumen jaminan/ agunan;

g. Dokumen lain yang diperlukan apabila ada.

3. Verifikasi data

Keputusan kredit sangat dipengaruhi oleh keakuratan data dan informasi. Untuk itu, verifikasi diperlukan untuk memastikan keabsahan data dan kesesuaian dengan fakta, di antaranya dengan beberapa metode berikut

\section{On the Spot Checking (OTS)}

OTS adalah kunjungan langsung ke tempat usaha/ domisili (calon) debitur yang dimaksudkan untuk mengecek kebenaran data dengan melihat secara fisik tempat usaha/domisili dan agunan, serta menggali aktivitas usaha debitur.

\section{Bank Checking}

Bank Checking dimaksudkan untuk mengecek informasi kredit yang pernah diperoleh debitur sebelumnya beserta kolektibilitasnya. Metode credit checking dapat dilakukan melalui sistem internal bank dan Informasi Debitur Individual (IDI) kepada Bank Indonesia. IDI BI adalah informasi mengenai individu atau suatu perusahaan dalam berhubungan dengan bank, fasilitas kredit yang diperoleh, kolektibilitas, dan informasi kredit lainnya.

6. Trade Checking atau Personal Checking untuk Kredit Konsumsi Trade checking dimaksudkan untuk mengetahui/menilai debitur dalam menjalankan kegiatan bisnisnya, hubungan dagang yang telah dilakukan oleh calon debitur, dan bagaimana manajemen perusahaan/debitur dalam melakukan kegiatan bisnisnya. Trade Checking dilakukan kepada 
sejumlah supplier, pelanggan, distributor, asosiasi terkait usaha debitur, dan pihak lain yang dipandang perlu oleh bank. Checking juga dapat dilakukan dengan kunjungan/penilaian langsung ke lapangan/market checking (misal, ke pasar) untuk mengetahui brand image dari produk debitur. Untuk kredit konsumsi, checking dilakukan atas kebenaran data personel calon debitur, antara lain data tempat tinggal, penghasilan, pekerjaan, legalitas usaha, dan omzet penjualan (untuk debitur wirausaha).

Pelaksanaan pemberian kredit bank memiliki resiko tinggi, dimana pihak bank sudah mengetahui hal tersebut. Adanya resiko gugatan pihak lain yang berhak terhadap kepemilikan objek Hak tanggungan debitur merupakan salah satu yang banyak terjadi. Gugatan pihak lain yang berhak terhadap kepemilikan objek Hak Tanggungan debitur banyak terjadi ketika pelaksanaan eksekusi lelang. Eksekusi lelang merupakan upaya perlindungan kreditur untuk mendapatkan pelunasan piutangnya apabila debitur tidak dapat memenuhi prestasinya. Dapat disimpulkan dalam hal proses pemberian kredit agar berjalan lancar dan mendapat pelunasan piutang kembali, setiap Bank harus menerapkan asas kehati-hatian dalam melaksanakan kegiatan usaha.

Terdapat 5 (lima) prinsip dalam perkreditan yang dapat memberikan informasi mengenai itikad baik dan kemampuan membayar nasabah untuk melunasi kembali pinjaman beserta bunganya. Kelima prinsip tersebut adalah: ${ }^{8)}$

1. Character (kepribadian)

Dengan berbekal pengalaman di lapangan, kepribadian seseorang dapat diketahui melalui gaya bicara, temperamen, kebiasaan sehari-hari, gaya hidup, pergaulan dan track record dengan rekan-rekan bisnisnya

2. Capacity(kemampuan)

Selain mengetahui sumber pembayaran, juga bagaimana prediksi keberhasilan calon debitur dalam merealisasi rencana yang telah ditetapkan sesuai dengan budget yang diajukan dalam rangka pengajuan kredit. Kemampuan laba calon debitur dapat dilihat dari performance tahun lalu, sekarang dan akan datang

3. Capital (permodalan)

\footnotetext{
8) Baidrun Harun, Penyelesaian Sengketa Kredit Bermasalah: Solusi Hukum dan Alternatif Penyelesaian Segala Jenis Kredit Bermasalah (Yogyakarta: Pustaka Yustisia, 2010), hal. 13.
} 
Modal merupakan hal yang sangat penting, karena ada kalanya bank mensyaratkan berapa maksimum pinjaman yang wajar dibanding dengan total modal yang dimiliki debitur

4. Condition of Economic (kondisi ekonomi)

Faktor ekonomi sangat berpengaruh terhadap kelangsungan hidup usaha calon debitur, sebelum mengetahui secara mendalam mengenai bisnis calon debitur

5. Collateral (jaminan)

Jaminan utama pinjaman adalah kelayakan dari usaha itu sendiri sedangkan jaminan tambahan ada dua yaitu jaminan material dan non material. Untuk menghindari terjadinya pemalsuan bukti pemilikan, maka sebelum dilakukan pengikatan harus diteliti mengenai status yuridisnya bukti pemilikan dan orang yang menjaminkan.Hal ini dimaksudkan untuk menghindari gugatan oleh pemilik jaminan yang sah.

Bank dalam pemberian kredit, selain menerapkan prinsip-prinsip di atas juga menerapkan apa yang dinamakan prinsip 5P sebagai berikut: ${ }^{9)}$

1. $\quad \operatorname{Party}($ para pihak)

Para pihak merupakan titik sentral yang diperhatikan dalam setiap pemberian kredit.Untuk itu para pemberi kredit harus memperoleh suatu "kepercayaan" terhadap para pihak, yang dalam hal ini adalah debitur.Bagaimana karakternya, kemampuannya, dan sebagainya.

2. Purpose (tujuan)

Tujuan dari pemberian kredit juga sangat penting diketahui oleh pihak kreditur. Harus dilihat apakah kredit akan digunakan untuk hal-hal yang positif yang benar-benar dapat menaikkan pendapatan. Harus pula diawasi agar kredit tersebut benar-benar diperuntukkan untuk tujuan seperti yang diperjanjikan dalam suatu perjanjian kredit.

3. Payment (pembayaran)

Harus pula diperhatikan apakah sumber pembayaran kredit dari calon debitur cukup tersedia dan aman, sehingga dengan demikian diharapkan bahwa kredit yang akan diluncurkan tersebut dapat dibayar kembali oleh debitur yang bersangkutan. Jadi harus dilihat dan dianalisis apakah setelah pemberian kredit nanti debitur mempunyai sumber pendapatan, dan apakah pendapatan tersebut cukup untuk membayar kembali kreditnya.

4. Profitability (perolehan laba)

Unsur perolehan laba oleh debitur tidak kurang pula pentingnya dalam suatu pemberian kredit. Untuk itu, kreditur harus berpartisipasi apakah laba yang akan diperoleh lebih besar dari bunga pinjaman dan apakah dapat menutupi pembayaran kembali kredit.

5. Protection (perlindungan)

\footnotetext{
${ }^{9}$ Munir Fuady, Hukum Perkreditan Kontemprer, (Bandung: PT Citra Aditya Bakti, 1996), hal. 2426.
} 


\begin{abstract}
Diperlukan suatu perlindungan terhadap kredit oleh perusahaan debitur.Terutama untuk berjaga-jaga sekiranya terjadi hal-hal di luar prediksi semula.
\end{abstract}

UU Hak Tanggungan juga mengatur perlindungan hukum bagi kreditur antara lain terdapat di Pasal 1, Pasal 6, Pasal 7, Pasal 14, dan Pasal 20.

Pasal 1 ayat (1) UU Hak Tanggungan berbunyi:

"Hak Tanggungan atas tanah berserta tanah beserta bendabenda yang berkaitan dengan tanah, yang selanjutnya disebut Hak Tanggungan, adalah hak jaminan yang dibebankan pada hak atas tanah sebagaimana dimaksud dalam Undang-Undang Nomor 5 Tahun 1960 tentang Peraturan Dasar Pokok-Pokok Agraria, berikut atau tidak berikut benda-benda lain yang merupakan satu kesa-tuan dengan tanah itu, untuk pelunasan utang tertentu, yang memberikan kedudukan yang diutamakan kepada kreditor tertentu terhadap kreditor-kreditor lain."

Pasal tersebut menjelaskan bahwa kreditur memiliki kedudukan yang diutamakan sebagai kreditur preferan untuk mendapatkan perlindungan hukum kreditur.Kedudukan kreditur lebih diutamakan dari pada kreditur kreditur lainnya.Jaminan yang dibebani hak tanggungan memberikan perlindungan hukum bagi kreditur pemegang hak tanggungan.Hal itu disebabkan karena sesuai Pasal 7 UU Hak Tanggungan yang berbunyi "Hak Tanggungan tetap mengikuti obyeknya dalam tangan siapapun obyek tersebut berada". Asas tersebut merupakan jaminan khusus bagi kepentingan pemegang Hak Tanggungan, yaitu walaupun obyek Hak Tanggungan sudah berpindah dan menjadi milik pihak lain, kreditur masih tetap dapat menggunakan haknya melalui eksekusi apabila debitur cidera janji.

Pasal 6 UU Hak Tanggungan juga memberikan perlindungan bagi kreditur tentang eksekusi. Pasal 6 UU Hak Tanggungan berbunyi:

“Apabila debitor cidera janji, pemegang Hak Tanggungan pertama mempunyai hak untuk menjual obyek Hak Tanggungan atas kekuasaan sendiri melalui pelelangan umum serta mengambil pelunasan piutangnya dari hasil penjualan tersebut. “

Pasal 6 UU Hak Tanggungan ini sudah sejalan dengan peraturan Pasal 1178 ayat (2) KUHPerdata tentang Hipotek, berdasarkan Pasal 6 UU Hak 
Tanggungan tersebut menjelaskan bahwa dalam hal pada Akta Pemberian Hak Tanggungan telah diperjanjikan bahwa pemegang Hak Tanggungan pertama mempunyai hak untuk menjual sendiri objek Hak Tanggungan apabila debitor cidera janji, maka kreditor pemegang Hak Tanggungan Pertama dapat langsung menjual objek Hak Tanggungan atas kekuasaan sendiri dengan cara lelang melalui Kantor Pelayanan Kekayaan Negara dan Lelang (KPKNL).

Pasal 14 ayat (1), (2), (3) UU Hak Tanggungan memberikan perlindungan bagi kreditur tentang penerbitan sertifikat Hak Tanggungan. Pasal 14 ayat (1), (2), (3) UU Hak Tanggungan berbunyi:

1. Sebagai tanda bukti adanya Hak Tanggungan, Kantor Pertanahan menerbitkan sertipikat Hak Tanggungan sesuai dengan peraturan perundang-undangan yang berlaku.

2. Sertipikat Hak Tanggungan sebagaimana dimaksud pada ayat (1) memuat irah-irah dengan kata-kata "DEMI KEADILAN BERDASARKAN KETUHANAN YANG MAHA ESA"

3. Sertipikat Hak Tanggunan sebagaimana dimaksud pada ayat (2) mempunyai kekuatan eksekutorial yang sama dengan putusan pengadilan yang telah memperoleh kekeuatan hukum tetap dan berlaku sebagai pengganti grosse akta Hipotek sepanjang mengenai hak atas tanah.

Sebagai tanda bukti adanya Hak Tanggungan, maka kantor Pertanahan menerbitkan sertifikat Hak Tanggungan. Penerbitan sertifikat ini berfungsi untuk melindungi kreditur yang hendak menjual obyek Hak Tanggungan dengan menggunakan sertifikat Hak Tanggungan. Sertifikat Hak Tanggungan ini mempunyai kekuatan yang sama dengan putusan hakim.

Pasal 20 UU Hak Tanggungan berfungsi untuk melindungi kedudukan kreditur yang preference. Pasal 20 UU Hak Tanggungan ini berbunyi:

1. Apabila debitor cidera janji, maka berdasarkan :

a. Hak pemegang Hak Tanggungan pertama untuk menjual obyek Hak Tanggungan sebagaimana dimaksud dalam Pasal 6, atau

b. Titel eksekutorial yang terdapat dalam sertipikat Hak Tanggungan sebagaimana dimaksud dalam Pasal 14 ayat (2), obyek Hak Tanggungan dijual melalui pelelangan umum menurut tata cara yang ditentukan dalam peraturan perundang-undangan untuk pelunasan piutang pemegang Hak Tanggungan dengan hak mendahulu dari pada kreditor-kreditor lainnya. 
2. Atas kesepakatan pemberi dan pemegang Hak Tanggungan, penjualan obyek Hak Tanggungan dapat dilaksanakan di bawah tangan jika dengan demikian itu akan dapat diperoleh harga tertinggi yang mengun-tungkan semua pihak.

3. Pelaksanaan penjualan sebagaimana dimaksud pada ayat (2) hanya dapat dilakukan setelah lewat waktu 1 (satu) bulan sejak diberitahukan secara tertulis oleh pemberi dan/atau pemegang Hak Tanggungan kepada pihak-pihak yang berkepentingan dan diumumkan sedikit-dikitnya dalam 2 (dua) surat kabar yang beredar di daerah yang bersangkutan dan/atau media massa setempat, serta tidak ada pihak yang menyata-kan keberatan.

4. Setiap janji untuk melaksanakan eksekusi Hak Tang-gungan dengan cara yang bertentangan dengan keten-tuan pada ayat (1), ayat (2), dan ayat (3) batal demi hukum.

5. Sampai saat pengumuman untuk lelang dikeluarkan, penjualan sebagaimana dimaksud pada ayat (1) dapat dihindarkan dengan pelunasan utang yang dijamin dengan Hak Tanggungan itu beserta biaya-biaya eksekusi yang telah dikeluarkan.

Pasal 20 UU Hak Tanggungan ini memberikan perlindungan bagi kreditur pemegang Hak Tanggungan, dimana kreditur berhak untuk mengajukan eksekusi dan melakukan lelang terhadap objek Hak Tanggungan demi memenuhi hak dari kreditur apabila debitur cidera janji atau wanprestasi. Kreditur berhak menjual objek Hak Tanggungan melalui pelelangan umum atau penjualan dibawah tangan.

Pasal pasal tersebut mengatur mengenai eksekusi objek jaminan Hak Tanggungan yang menjadi perlindungan hukum untuk kreditur bila debitur tidak dapat memenuhi prestasinya. Undang Undang Hak Tanggungan tidak mengatur perlindungan hukum bagi kreditur apabila terjadi gugatan pihak lain yang berhak atas objek jaminan yang mengakibatkan batalnya perjanjian kredit.

Upaya perlindungan hukum yang diuraikan diatas bukan merupakan peraturan khusus untuk melindungi kreditur dalam hal terjadi gugatan lain yang berhak atas objek jaminan yang dibebani Hak Tanggungan. UU Perbankan dan UU Hak Tanggungan hanya mengatur perlindungan hukum bagi kreditur apabila debitur tidak dapat memenuhi prestasinya (wanprestasi) sehingga digolongkan sebagai kredit macet dan proses pengembalian utang dengan cara melalui eksekusi lelang. Perlindungan hukum bagi kreditur atas gugatan pihak lain yang berhak atas objek jaminan yang dibebani hak tanggungan belum diatur secara khusus. 
Perlindungan hukum bagi kreditur apabila mendapatkan gugatan dari pihak lain yang berhak atas agunan hanya dapat diselesaikan dengan menggunakan aturan yang terdapat pada Pasal 1131 dan Pasal 1132 KUHPerdata.

Hak Tanggungan termasuk dalam jaminan umum karena Hak Tanggungan merupakan benda tidak bergerak sehingga kreditur dapat dilindungi dengan menggunakan pasal 1131 dan 1132 KUHPerdata.Pasal 1131 KUHPerdata berisi "Segala barang-barang bergerak dan tak bergerak milik debitur, baik yang sudah ada maupun yang akan ada, menjadi jaminan untuk perikatan-perikatan perorangan debitur itu”. Pasal 1132 KUHPerdata sendiri berisi:

"Kebendaan tersebut menjadi jaminan bersama-sama bagi semua orang yang mengutangkan padanya, pendapatan penjualan benda-benda itu dibagi-bagi menurut keseimbangan, yaitu menurut besar kecilnya piutang masing-masing, kecuali apabila di antara para berpiutang itu ada alasan-alasan untuk didahulukan."

Perlindungan kreditur atas pelunasan utang debitur menggunakan pasal 1131 dan pasal 1132 KUHPerdata membuat posisi kreditur menjadi kreditur konkuren, jika dalam UU Perbankan dan UU Hak Tanggungan kedudukan kreditur bersifat preferen karena secara khusus dilindungi hak-haknya apabila terjadi kredit macet. Kreditur yang kedudukannya berubah menjadi konkuren tetap akan mendapatkan perlindungan terhadap hak pengembalian piutangnya.

\section{B. Upaya hukum yang dapat ditempuh kreditur untuk melindungi hak hak nya} terhadap sengketa agunan yang mengakibatkan batalnya perjanjian kredit.

Proses pelaksanaan pemberian kredit oleh kreditur kepada debitur memiliki resiko yang tinggi. Resiko yang sering dialami Bank adalah proses pengembalian piutang yang tidak terlaksana tepat waktu. Banyak peraturan yang muncul mengenai perlindungan bagi kreditur untuk mengurangi resiko yang akan terjadi. Kenyataan yang ada menunjukkan bahwa posisi debitur sebagai seorang berposisi lemah sedangkan kreditur sebagai seorang yang berposisi kuat.Hal tersebut disebabkan karena debitur merupakan seseorang yang membutuhkan dalam pelaksanaan kredit sedangkan kreditur yang memberikan fasilitas kredit. 
Posisi kreditur dapat dikatakan sebagai posisi yang kuat namun tidak dapat memberikan jaminan akan hak-hak kreditur akan terlindungi sepenuhnya.

Ketentuan ketentuan hukum yang menjamin dan memberikan perlindungan kepada hak kreditur tersebut dapat ditemukan dalam Kitab Undang Undang Hukum Perdata, UU Nomor 4 Tahun 1996 tentang Hak Tanggungan, UU Nomor 10 Tahun 1998 tentang Perubahan UU Nomor 7 Tahun 1992 tentang Perbankan. Pelaksanaan ketentuan ketentuan hukum tersebut tergantung dari kreditur untuk mempertahankan hak hak nya serta itikad baik dari para pelaksana penegak hukum terutama para hakim dari semua tingkat peradilan.Dalam penanganan kredit macet, perbankan saat ini kurang memberikan perlindungan terhadap hak hak kreditur.Upaya menangani kredit macet tersebut pemerintah tidak menerapkan hukum yang ada tetapi menerapkan peraturan hukum baru.Peraturan hukum yang baru hanya membuat pelaksanaan pelunasan piutang kreditur menjadi terhambat.

Keputusan menteri keuangan Nomor 106/PMK.06/2013 yang mengatur bahwa pelaksanaan lelang eksekusi harus diberhentikan apabila terdapat gugatan pihak ketiga selain debitur/ tereksekusi terhadap kepemilikan objek jaminan.Peraturan mengenai penyelesaian masalah pelunasan piutang kreditur tidak terjamin. Peraturan itu malah berdampak menghambat proses pengembalian piutang dalam kegiatan usaha Bank selaku kreditur yang berakibat pada kesehatan Bank dan dana masyarakat.

Putusan MA Nomor 3201K/PDT/1984 tanggal 30 Januari 1986, hukum positif Indonesia juga menyediakan beberapa alternative yang dapat ditempuh oleh kreditur dalam mengambil pelunasan kembali atas piutang yang mengalami kemacetan dalam pengembaliannya, yaitu:

a. Mengajukan gugatn secara perdata

b. Mengajukan permohonan eksekusi atas dasar Pasal $224 \mathrm{HIR}$;

c. Menyerahkan kepada Panitia Urusan Piutang Negara (PUPN);

d. Mengajukan permohonan lelang atas dasar Pasal 1178 ayat (2) BW;

e. Melakukan penjualan dibawah tangan atas dasar Pasal 17 ayat (1) UU Nomor 16 Tahun 1985 tentang Rumah Susun (UURS). 
Sesuai peraturan peraturan diatas, Bank juga memiliki upaya dalam pengembalian piutangnya. Upaya pengembalian piutang dengan eksekusi diatur dalam Pasal 20 Undang Undang Hak Tanggungan yang berisi:

1. Apabila debitor cidera janji, maka berdasarkan :

a. Hak pemegang Hak Tanggungan pertama untuk menjual obyek Hak Tanggungan sebagaimana dimaksud dalam Pasal 6, atau

b. Titel eksekutorial yang terdapat dalam sertipikat Hak Tanggungan sebagaimana dimaksud dalam Pasal 14 ayat (2), obyek Hak Tanggungan dijual melalui pelelangan umum menurut tata cara yang ditentukan dalam peraturan perundang-undangan untuk pelunasan piutang pemegang Hak Tang-gungan dengan hak mendahulu dari pada kreditor-kreditor lainnya.

2. Atas kesepakatan pemberi dan pemegang Hak Tang-gungan, penjualan obyek Hak Tanggungan dapat dilaksanakan di bawah tangan jika dengan demikian itu akan dapat diperoleh harga tertinggi yang mengun-tungkan semua pihak.

3. Pelaksanaan penjualan sebagaimana dimaksud pada ayat (2) hanya dapat dilakukan setelah lewat waktu 1 (satu) bulan sejak diberitahukan secara tertulis oleh pemberi dan/atau pemegang Hak Tanggungan kepada pihak-pihak yang berkepentingan dan diumumkan sedikit-dikitnya dalam 2 (dua) surat kabar yang beredar di daerah yang bersangkutan dan/atau media massa setempat, serta tidak ada pihak yang menyata-kan keberatan.

4. Setiap janji untuk melaksanakan eksekusi Hak Tanggungan dengan cara yang bertentangan dengan keten-tuan pada ayat (1), ayat (2), dan ayat (3) batal demi hukum.

5. Sampai saat pengumuman untuk lelang dikeluarkan, penjualan sebagaimana dimaksud pada ayat (1) dapat dihindarkan dengan pelunasan utang yang dijamin dengan Hak Tanggungan itu beserta biaya-biaya eksekusi yang telah dikeluarkan.

Indonesia memiliki beberapa alternatif penyelesaian sengketa yang digunakan yaitu upaya litigasi dan non litigasi. Litigasi pada kenyataannya disebut sebagai gugatan.Menurut Sudikno Mertokusumo gugatan adalah tuntutan hak yaitu tindakan yang bertujuan memberikan perlindungan yang diberikan oleh pengadilan untuk mencegah perbuatan main hakim sendiri (eigenrichting). ${ }^{10}$

Upaya non litigasi juga telah diatur dalam Undang Undang Nomor 30 Tahun 1999 tentang Arbitrase dan Alternatif Penyelesaian Sengketa. Undang Undang itu lahir guna penyelesaian sengketa perdata di samping dapat diajukan

\footnotetext{
${ }^{10}$ Sudikno Mertokusumo, Hukum Acara Perdata Indonesia, (Yogyakarta: Liberty. 2002), hal. 52.
} 
ke peradilan umum juga terbuka kemungkinan diajukan melalui arbitrase dan alternatif penyelesaian sengketa.

Alternatif penyelesaian sengketa non litigasi yang dimiliki Indonesia antara lain:

a. Negosiasi

Negosiasi adalah komunikasi dua arah dirancang untuk mencapai kesepakatan pada saat kedua belah pihak memiliki berbagai kepentingan yang sama atau berbeda. Negosiasi dapat dibagi menjadi 2 (dua) yaitu negosiasi yang bersifat positif dan negosiasi yang bersifat negatif. Negosiasi yang bersifat positif berarti para pelaku negosiasi hendak mencapai suatu perjanjian yang bersifat kerja sama. Negosiasi yang bersifat negatif berarti jika para pelaku negosiasi hendak mencapai perdamaian. $^{11)}$

b. Mediasi

Mediasi adalah cara penyelesaian sengketa antara dua pihak atau lebih dengan perantaraan pihak ketiga, yakni pihak yang memberi masukan masukan kepada para pihak untuk menyelesaikan sengketa mereka.Biasanya, pihak ketiga, mediator membantu para pihak untuk bernegosiasi penyelesaian.Mediator bertindak sebagai pihak ketiga yang netral dan memfasilitasi dari pada mengarahkan proses. Pada mediasi, tidak terdapat kewajiban dari masing masing pihak untuk menaati apa yang disarankan mediator. ${ }^{12)}$

c. Konsiliasi/ perdamaian

Konsiliasi adalah proses dimana para pihak dalam sengketa setuju untuk memanfaatkan jasa seorang konsiliator, yang kemudian bertemu dengan pihak pihak secara terpisah dalam upaya untuk menyelesaikan perbedaan mereka. Konsiliasi pada praktiknya hampir sama dengan mediasi, yang membedakan adalah kewenangan dari pihak ketiga yang menengahi sengketa tersebut. Pada mediasi, pihak ketiga yang menengahi sengketa tidak memiliki kewenangan untuk memaksa para pihak mematuhi keputusan yang diambil, sedangkan pada konsiliasi, pihak ketiga yang menengahi sengketa tersebut memiliki kewenangan untuk memaksa para pihak untuk mematuhi keputusan yang diambil. Konsiliasi dan arbitrase memiliki kesamaan, yakni adanya pihak ketiga yang menengahi sengketa tersebut dan memiliki kewenangan untuk memutuskan dan memkasa para pihak untuk menaati hal yang diputuskan pihak ketiga. Konsiliator pada proses konsiliasi pada umumnya adalah mereka yang telah diangkat dan disetujui oleh menteri yang berkaitan dengan bidang yang dijalani oleh konsiliayor sehingga terdapat hubungan antara konsiliator dan instansi pemerintah. ${ }^{13)}$

\footnotetext{
11)Jimmy Joses Sembiring, Cara Menyelesaikan Sengketa di Luar Pengadilan (Jakarta: Visi Media.2011), hal. 16-17

${ }^{12)}$ Ibid., hal. 28.

${ }^{13)}$ Ibid., hal. 47-48
} 


\section{d. Arbitrase}

Arbitrase adalah penyelesaian sengketa melalui arbiter berdasarkan kebijaksanaanya. Arbitrase memiliki beberapa unsur antara lain: penyelesaian sengketa secara privat atau diluar pengadilan, arbitrase atas dasar perjanjian tertulis dari para pihak, arbitrase bertujuan untuk mengantisipasi sengketa yang mungkin terjadi atau yang sudah terjadi, melibatkan pihak ketiga, dan sifat putusannya adalah mengikat. ${ }^{14)}$

Jika upaya upaya diatas tidak membuahkan hasil maka bank akan menempuh jalur hukum untuk mendapatkan hak atas pelunasan piutangnya.

Gugatan dari pihak lain terhadap kepemilikan agunan yang sedang dihadapi Bank PT Permodalan Nasional Madani unit Cepu yaitu gugatan yang diajukan oleh Bagus Satriya atas pengembalian hak terhadap tanah didaerah Tambakromo. Bagus Satriya merupakan suami sah dari Erlinawati.Tanah di daerah Tambakromo merupakan harta bersama yang didapatkan selama perkawinan.

Gugatan yang di hadapi PT Permodalan Nasional Madani disebabkan karena objek jaminan yang dijadikan jaminan merupakan milik bersama, namun dijaminkan tanpa sepengetahuan dan persetujuan dari pihak yang berhak. Sehingga menimbulkan sengketa dikemudian hari.

Pasal 1865 KUHPerdata yang berbunyi:

"Setiap orang yang mengaku mempunyai hak, atau menunjuk suatu peristiwa untuk meneguhkan haknya itu atau untuk membantah suatu hak orang lain, wajib membuktikan adanya hak itu atau kejadian yang dikemukakan itu."

Pasal 1866 KUHPerdata berbunyi, "Alat pembuktian meliputi: bukti tertulis, bukti saksi, persangkaan, pengakuan dan sumpah”

Peraturan Pasal 1865 dan 1866 KUHPerdata itu menjelaskan bahwa Bank dalam mengambil langkah berperkara di Pengadilan diperlukan perlindungan melalaui proses pembuktian. Bank mendapatkan kewajiban untuk menunjukkan bukti akta atau sertifikat dari perjanjian awal kredit sampai pada kepemilikan sertifikat Hak tanggungan, mengajukan saksi-saksi, dan lain sebagainya yang

\footnotetext{
14)Tommirrosandy, "Pengantar Hukum Arbitrase di Indonesia", https://tommirrosandy.wordpress.com/2011/03/14/pengantar-hukum-arbitrase-di-indonesia/ diakses tanggal 25 April 2018.
} 
dimiliki. Jika hal hal tersebut menjadi bukti yang kuat dalam persidangan akan membuat hak ban dalam pelunasan piutang dapat terlaksana.

Kedua peraturan diatas menjelaskan bahwa bank memiliki perlindungan terhadap pelunasan piutangnya. Meskipun terdapat gugatan pihak lain terhadap objek jaminan yang dijadikan Hak Tanggungan, bank tetap berhak atas pelunasan piutangnya. Upaya yang harus dilakukan bank adalah melakukan upaya litigasi berperkara perdata sesuai dengan Putusan MA Nomor 3201 K/Pdt/1984. Bank diluar upaya tersebut juga dapat mencari jalan keluar non litigasi dengan debitur untuk melunasi hutangnya.

\section{III.Penutup}

\section{A. Kesimpulan}

Perlindungan hukum bagi kreditur pemegang Hak Tanggungan terhadap sengketa agunan yang mengakibatkan batalnya perjanjian kredit belum diatur secara khusus pada peraturan perundang undangan. Peraturan perundang undangan hanya mengatur tentang kredit macet dan pelunasan hutang melalui proses eksekusi. Apabila kreditur mendapatkan gugatan terhadap objek agunan, maka kreditur dapat menggunakan Jaminan Umum yang diatur dalam KUHPer pasal 1131 dan 1132 sebagai perlindungan hukum.

Upaya hukum yang dapat ditempuh kreditur terhadap sengketa agunan yang mengakibatkan batalnya perjanjian kredit adalah:

1. Upaya non litigasi

Upaya non litigasi terdiri dari negosiasi, mediasi, konsiliasi/ perdamaian, dan arbitrase. Upaya non litigasi ini merupakan upaya yang ditempuh diluar jalur hukum.

2. Upaya litigasi

Upaya litigasi ditempuh apabila upaya non litigasi tidak mencapai kesepakatan bersama. Upaya litigasi merupakan upaya menyelesaikan perkara secara hukum.Upaya litigasi yang dapat ditempuh bank adalah dengan cara mengajukan gugatan ke pengadilan. 


\section{B. Saran}

1. Bagi bank

Bank sebelum memberikan kredit dengan jaminan hak tanggungan sebaiknya menerapkan prinsip kehati hatian sesuai dengan Pasal 2 UU perbankan agar terhindar dari resiko kredit macet atau mengalami sengketa agunan yang dapat mengakibatkan gugatan dari pihak lain. Jika bank dapat menerapkan prinsip kehati hati an resiko bank mengalami kendala akan menjadi kecil.

2. Bagi pemerintah

Pemerintah sebaiknya membuat peraturan baru mengenai perlindungan hukum bagi kreditur jika mengalami sengketa agunan yang mengakibatkan batalnya perjanjian kredit.Sejauh ini peraturan pemerintah hanya memberikan perlindungan hukum kepada kreditur yang mengalami kredit macet dan peraturan mengenai pelaksanaan lelang.

\section{Daftar Pustaka}

\section{A. Buku}

Adjie, Habib. Hak Tanggungan sebagai Lembaga Jaminan atas Tanah. Bandung: Mandar Maju, 2000.

Fuady, Munir. Hukum Perkreditan Kontemprer.Bandung: PT Citra Aditya Bakti, 1996.

Harun, Baidrun.Penyelesaian Sengketa Kredit Bermasalah: Solusi Hukum dan Alternative Penyelesaian Segala Jenis Kredit Bermasalah. Yogyakarta: Pustaka Yustisia, 2010.

Hermansyah. Hukum Perbankan Nasional Indonesia. Jakarta: Kencana, 2005.

Rahman, Hassanudin. Aspek-Aspek Hukum Pemberian Kredit Perbankan di Indonesia.Bandung : PT Citra Aditya Bakti, 1995.

Sembiring, Jimmy Joses. Cara Menyelesaikan Sengketa di Luar Pengadilan.Jakarta: Visi Media, 2011.

Siamat, Dahlan. Manajemen Lembaga Keuangan. Jakarta: Intermedia, 1995. 


\section{B. Peraturan Perundang-Undangan}

Indonesia, Undang-undang Nomor 10 Tahun 1998 tentang Perubahan Undangundang Nomor 7 Tahun 1992 tentang Perbankan (Tambahan Lembaran Negara Republik Indonesia Nomor 3472).

\section{Putusan Pengadilan}

Indonesia. Mahkamah Agung Jakarta Nomor 1217K/Pdt/2016

\section{Artikel Internet}

Anonim. "Proses Pemberian Kredit". http://www.upacaya.com/proses-pemberiankredit/ (5 April 2018).

Tommirrosandy. "Pengantar Hukum Arbitrase di Indonesia". https://tommirrosandy.wordpress.com/2011/03/14/pengantar-hukumarbitrase-di-indonesia/ (25 April 2018) 